Science in Context

http://journals.cambridge.org/SIC

Additional services for Science in Context:

Email alerts: $\underline{\text { Click here }}$

Subscriptions: Click here

Commercial reprints: $\underline{\text { Click here }}$

Terms of use : $\underline{\text { Click here }}$

\title{
Early Texts on Hindu-Arabic Calculation
}

\section{Menso Folkerts}

Science in Context / Volume 14 / Issue 1-2 / June 2001, pp 13 - 38

DOI: 10.1017/S0269889701000023, Published online: 10 September 2002

Link to this article: http://journals.cambridge.org/abstract_S0269889701000023

How to cite this article:

Menso Folkerts (2001). Early Texts on Hindu-Arabic Calculation. Science in Context, 14, pp 13-38 doi:10.1017/ S0269889701000023

Request Permissions : $\underline{\text { Click here }}$ 


\title{
Early Texts on Hindu-Arabic Calculation
}

\section{Menso Folkerts}

\author{
Ludwig-Maximilians-Universität München
}

\section{Argument}

This article describes how the decimal place value system was transmitted from India via the Arabs to the West up to the end of the fifteenth century. The arithmetical work of alKhwārizmī's, ca. 825, is the oldest Arabic work on Indian arithmetic of which we have detailed knowledge. There is no known Arabic manuscript of this work; our knowledge of it is based on an early reworking of a Latin translation. Until some years ago, only one fragmentary manuscript of this twelfth-century reworking was known (Cambridge, UL, Ii.6.5). Another manuscript that transmits the complete text (New York, Hispanic Society of America, HC 397/726) has made possible a more exact study of al-Khwārizmī's work. This article gives an outline of this manuscript's contents and discusses some characteristics of its presentation.

\section{Indian, Arabic, and Western Arithmetic}

The decimal system, with nine digits and the zero, comes from India. ${ }^{1}$ At first there were individual symbols for the units and the tens, so that the system differed little from the alphabetical systems used by many peoples, for example the Greeks. The decisive step came when somebody used the same digits for the tens, hundreds, etc. as for the units. So began the "place-value" system for base 10. The oldest example of numbers so written are those of the Gurjara Inscription (595 A.D.), but it is generally assumed that the system goes back at least as far as the first centuries A.D. From the eighth century inscriptions and manuscripts with these numbers become relatively numerous. The oldest known occurrence of the zero in India is in 870, in the Gwalior inscriptions, and was in circular form. It was called śūnya (empty). In other documents the zero is written as a dot. ${ }^{2}$ There are examples of the "Indian" decimal place-value system from seventh-century Cambodia, Sumatra, and Java.

The decimal place-value system was also known to mathematicians outside India at least as early as the seventh century: the Syrian scholar Severus Sebokht mentioned

\footnotetext{
${ }^{1}$ For the history of the decimal system see, for instance, Bose, Sen and Subbarayappa 1971, 175-179, Ifrah 1986, Kap. 31, Smith 1925, 65-72, Juschkewitsch 1964a, 102-109, Tropfke 1980, 43-45, Lemay 1982.

${ }^{2}$ A useful survey of the development and the forms of the Indian numerals in India and the Arabic-speaking countries is to be found in Tropfke 1980, 66.
} 
the Indian numerals about 662, saying that their way of writing numbers with 9 digits is beyond all praise. This shows that the new numbers were known in the Near East before the translations into Arabic.

Originally the Indian numbers were used in written documents simply to record numbers; arithmetic operations were made on a calculation board. It appears that at first numbers in each denomination were represented by cowrie shells (or, presumably, by other counters), but numerals were later written with a sharpened stick on dust spread on the board, intermediate results being rubbed out.

In Indian mathematical writings arithmetic was presented in a series of rules. Fractions, particularly unit fractions, were treated in great detail. In contrast to Greek writers, the Indians used the sexagesimal system very little. Procedures to find square and cube roots, either exactly or approximately, were known, and it was recognized that the procedures could be made more exact by multiplying the number whose root was required by a power of ten. There were procedures to check arithmetic operations, for instance by the casting out of nines. ${ }^{3}$

In their many conquests beginning in the seventh century the Arabs took over the forms of the numbers found in the conquered territories - in the eastern Mediterranean, the Greek alphabetic system. Indian numerals, with the zero, were known to educated Muslims at least by the year 760. The oldest known Arabic example is " 260 " at the end of a papyrus document and may be the Hijra date, i.e. 873-74. Here the zero is represented by a dot. ${ }^{4}$ In the following centuries the Indian numerals became known throughout the Arabian empire from the eastern provinces to Spain. In the Fihrist (ca. 987) there is a section devoted to the writing of Indian numerals: the nine numerals are mentioned, with an example of each; the tens, hundreds, and thousands being distinguished by one, two, and three dots placed beneath the digits. ${ }^{5}$ The form of the numerals was not uniform; in particular, two conventions were developed, one in the East (including Egypt) and the other in North Africa and Spain. They differ in the way some of the numerals were written. ${ }^{6}$ Perhaps the oldest known eastern example of all nine digits and the zero is a manuscript which might have been written in Iran about $970,{ }^{7}$ and there are many other examples from later times. ${ }^{8}$ In contrast, the western Arabic numerals are known only from late specimens. ${ }^{9}$

\footnotetext{
${ }^{3}$ The fundamental work on Indian mathematics is still Datta and Singh 1935-1938. A good summary is Juschkewitsch 1964a, 89-174.

${ }^{4}$ See Smith and Karpinski 1911, 56. It is not certain that the number in question is a date, as generally assumed. Gandz $(1931,394)$ erroneously refers to these numerals as "earliest Arabic documents containing the ghubâr numerals."

${ }_{5}^{5}$ Flügel 1871-72, 1, 18-19; Dodge 1970, 34-35. See also Karpinski 1910-1911.

${ }^{6}$ The various forms are given, for example, in Tropfke 1980, 66.

${ }^{7}$ Paris, BN, ar. 2457, f. 81r-86r; some scholars believe that the manuscript was not written in the tenth but in the twelfth century. The forms of the numerals in this manuscript are reproduced in line 3 of the table in Smith and Karpinski 1911, 69.

${ }^{8}$ Irani (1955-1956, 4-10, col. A) reproduces the numerals of a manuscript written in 1082. In the same article there are drawn other numerals from more recent eastern Arabic manuscripts.

${ }^{9}$ The oldest examples given by Labarta and Barceló 1988 are from the fourteenth century.
} 
In the year 773 an embassy from India went to the court of Caliph al-Manșūr in Baghdad. Among the officials was a scholar with astronomical and mathematical expertise. He introduced Indian astronomy to the caliph's court, where an Indian astronomical treatise was translated into Arabic. ${ }^{10}$ Under Caliph al-Ma'mūn (reigned 813-833) translation activity reached its climax; many mathematical and astronomical works were translated from Greek. Subsequently the foreign sciences were assimilated into Arabic-Islamic culture.

Among the first who wrote mathematical works in Arabic was Muhammad ibn Mūsā al-Khwārizmī (ca. 780-ca. 850; fl. 830). He worked in the very center of a group of mathematicians and astronomers (and others) who were active in the "House of Wisdom" (Bayt al-hikma) in the time of Caliph al-Ma'mūn. He wrote on arithmetic, algebra, astronomy, geography, and the calendar. His treatises on arithmetic and algebra marked the beginning of Arabic writings on these subjects. ${ }^{11}$

Al-Khwārizmī's work on algebra must have been written before his Arithmetic, where it is cited. It is still not known which sources he used for the Algebra: we may assume that the questions and results of the Babylonians and Indians were available to him, but we do not know in what form. There are indications that there was also an oral tradition, and it may well be that he drew upon this as well as upon written works. He provided geometrical proofs for algebraic rules for solving quadratic equations, but these proofs were not taken over from Greek writings, for example, Euclid's Elements and Data.

Al-Khwārizmī's Algebra is divided into three parts:

- An algebraic section, followed by a short chapter on mercantile calculations illustrating the rule of three after the Indian fashion.

- A relatively short chapter on mensuration by using algebra.

- A section on inheritance problems according to Islamic law. It comprises more than half the book. ${ }^{12}$

There are several Arabic manuscripts of the Algebra. ${ }^{13}$ The first section was translated twice into Latin in the twelfth century, once by Robert of Chester (Segovia, 1145) and again by Gerard of Cremona (Toledo, second half of the twelfth century). ${ }^{14}$

The arithmetical treatise of al-Khwārizmī is the oldest known Arabic work in which the Indian decimal place-value system and operations with it are described.

\footnotetext{
${ }^{10}$ See Juschkewitsch 1964a, 179, and Saidan 1978, 6.

${ }^{11}$ For the life and work of al-Khwārizmī, see particularly Toomer 1973 and Sezgin 1974, 228-241.

${ }^{12}$ Analyzed in Gandz 1938.

${ }^{13}$ See Sezgin 1974, 240, 401.

${ }^{14}$ Edited by B. Hughes in Hughes 1986 and Hughes 1989.
} 
Unfortunately, there is no known Arabic manuscript. All that we have are Latin texts based upon a lost translation. Details will be given in part 2 .

The oldest extant Arabic texts on Indian arithmetic are from the middle of the tenth century or later, and so more than a hundred years later than al-Khwārizmī himself. There are modern editions of the following works:

- Abū 'l-Hasan Aḥmad ibn Ibrāhīm al-Uqlīdisī's al-Fuṣ̄̄l fī 'l-hisāā al-hind̄̄ (Chapters on Indian calculation). The treatise was written in Damascus in 952/953 and is the oldest extant work in Arabic on the subject. ${ }^{15}$

- Abū 'l-Hasan Kūshyār ibn Labbān's Fī usūl hisāa al-hind (On the elements of calculation of the Indians) from the second half of the tenth century. ${ }^{16}$

- Abū Manșūr 'Abd al-Qāhir ibn Ṭāhir al-Baghdādī’s Kitāb al-takmila fī 'l-hisāb (Book on the completion of calculation). Al-Baghdādī died in Isfarāyīn in 1037. ${ }^{\text {i7 }}$

Besides these, there are numerous Arabic texts on calculation. In 1978 A. S. Saidan compared al-Uqlīisī's text with all Arabic arithmetic texts of which details were known at the time and also with Indian treatises available to him (Saidan 1978).

The Indian numerals were known in the West before the translation of Arabic works into Latin. The oldest known examples are in two Latin manuscripts which were written in Spain towards the end of the tenth century: the Codex Vigilanus (976) and the Codex Emilianus (992), neither of them a mathematical text. The numerals from 1 to 9 appear here in the western Arabic form. ${ }^{18}$

This form of the numerals became well-known in monastic schools, because they were used on the calculation board (Latin: abacus). From the end of the tenth to the twelfth centuries there are numerous descriptions of calculating with the abacus, the oldest by Gerbert (ca. 940-1003). He probably became acquainted with these numerals during his visit to the Spanish Marches shortly before 970. Gerbert used the numerals, however, not for written calculations, but to mark counters for use on the abacus. ${ }^{19}$ From the eleventh century there were special names for the numerals so used; some of these were Latinized Arabic words. ${ }^{20}$ With the disappearance of Gerbert's abacus in the twelfth century, these names disappeared, too.

The west-Arabic forms of the numerals 1 to 9 are also known by the term ghubar numerals $(g h u b \bar{a} r=\mathrm{dust})$. These forms appeared in the West in treatises on the abacus as well as, somewhat later, in accounts of the new method of written calculation (see

\footnotetext{
${ }^{15}$ Edited in Saidan 1973; English translation and commentary in Saidan 1978.

${ }^{16}$ Edited in facsimile with English translation in Levey and Petruck 1965.

${ }^{17}$ Edited in Saidan 1985.

${ }^{18}$ See Smith and Karpinski 1911, 138. The relevant parts of both manuscripts are reproduced in van der Waerden and Folkerts 1976, 54, 55.

${ }^{19}$ The standard edition of Gerbert's mathematical writings is still Bubnov 1899. The most important recent studies on Gerbert's arithmetic are Lindgren 1976 and Bergmann 1985.

${ }^{20}$ For the names and their meanings see Ruska 1917, 82-92.
} 
below). There are considerable differences in the manuscripts in the forms of some of the numerals. These may be explained from their being drawn on the top of counters, which can be rotated. ${ }^{21}$

A new phase begins with the translations from Arabic into Latin in the twelfth century. Among the numerous works translated was al-Khwārizmī's Arithmetic. Unfortunately, no manuscript of the original Latin text is known. All that we have is a reworking, which begins with Dixit Algorizmi and is here referred to as DA (for details see below). The content of DA to a large extent prescribed the content of subsequent treatises on arithmetic in the West: the forms of the numerals and the principles of the place-value system; operations with integers (addition, subtraction, halving, doubling, multiplication, division); operations with fractions (multiplication, division, notation, addition, subtraction, doubling, halving); extracting square roots of integers and fractions. Not treated in DA are: arithmetic and geometric progressions, extraction of cube roots.

Of greater influence than DA were three redactions, all made in the twelfth century: the Liber Ysagogarum Alchorismi (LY), the Liber Alchorismi (LA) and the Liber pulveris (LP). ${ }^{22}$

The LY is a work apparently intended to cover the whole quadrivium. Of the five books, the first three are on arithmetic, the fourth on geometry and the fifth on astronomy. In the title of book 4, music is mentioned as well as geometry. The manuscripts of this text differ markedly. Three versions may be distinguished: LY I, II and III. LY I is usually assumed to be written before 1143, but this is by no means certain. LY II is an expanded version of LY I. In one of its manuscripts a scribe has written a Magistro A compositus. It has been supposed that Magister A is Adelard of Bath. LY III, written in France, is another redaction of the original Liber Ysagogarum.

LA, the second of the texts derived from al-Khwārizmī, shows Spanish influence. The author is named as magister Iohannes. It is not clear whether this "Iohannes" was John of Seville (Johannes Hispalensis), who translated several astronomical and astrological texts from Arabic between 1133 and 1142 .

LP is partly identical to LA, but also contains original parts. Apparently it is older than LA. We refer here to the common parts as LA/LP.

The three redactions - LY, LA, LP - treat by and large the same material in the same order as in DA, but the presentation is often clearer and more detailed, especially in LA/LP. The authors' efforts to present the material systematically and completely are easily recognizable.

Another treatise on Indian arithmetic was written in the twelfth century, though it was not widely known. One of the two manuscripts gives the author as H. Ocreatus and the title as Helceph Sarracenicum. ${ }^{23}$ The word "Helceph" comes from the Arabic al-hisäb (calculation). The author was acquainted with the new methods, but used

\footnotetext{
${ }^{21}$ See Beaujouan 1948.

${ }^{22}$ For details see the edition in Allard 1992 and the summary in Allard 1991.

${ }^{23}$ Edited with English translation in Burnett 1996, 261-297.
} 
Roman and not Arabic numerals and also terms from the old Western tradition - for example, from Boethius and the abacus treatises in the Gerbert tradition.

On the translation of al-Khwārizmī's Arithmetic and the three redactions (and not on the "Ocreatus" text) depend a series of texts on calculating with Hindu-Arabic numerals. They were called algorismus treatises, a name that goes back to "alKhwārizmī," though the historical connection was not understood, and the name was applied to any work of this kind. They were at first written in Latin and described the representation of numbers by Hindu-Arabic numerals and calculation with them (including sexagesimal and common fractions). Between the twelfth and fifteenth centuries a large number of such texts were written. In contrast to the earlier texts they generally treated either integers (Algorismus de integris) or fractions (Algorismus de minuciis). Among the writings on integers there are at least four texts that may with great probability be ascribed to the twelfth century: two algorismi in manuscripts now in London; the "Salem algorismus" and a text from Frankenthal. Though they differ in length, the content of these four treatises is essentially the same. ${ }^{24}$

In the first half of the thirteenth century two well-known authors wrote algorismus treatises which were of great influence in the following centuries: Alexander de Villa Dei (d. ca. 1240), Carmen de algorismo, ${ }^{25}$ and Johannes de Sacrobosco (d. 1236?), Algorismus vulgaris. ${ }^{26}$ Alexander de Villa Dei's work, written in hexameters, is somewhat earlier than Sacrobosco's. Both treatises are limited to calculations with integers. The success of these textbooks undoubtedly lies in the short and easy expression of each step of the various calculations and the lack of examples. These texts treat the subjects usually occurring in this kind of literature.

There appeared in the thirteenth century a number of treatises of a different character. They seem to have been written partly by Jordanus de Nemore, partly by members of his circle. Besides the usual arithmetical operations, they also treat more general mathematical and philosophical questions. ${ }^{27}$

The best-known textbook on fractions, the Algorismus de minutiis, was written by Johannes de Lineriis about $1320 .{ }^{28}$ It shows little originality and is characterized by having no proofs, only rules and examples. In general style it is similar to the Algorismus vulgaris of Johannes de Sacrobosco and was a text that could easily be studied.

The arithmetical works of Johannes de Sacrobosco, Alexander de Villa Dei and Johannes de Lineriis were soon adopted by universities and became standard textbooks in the faculty of the artes liberales. With the help of these books arithmetic with Hindu-Arabic numerals was taught both in universities and grammar-schools.

\footnotetext{
${ }^{24}$ Edited in Karpinski 1921, Cantor 1865, Allard 1978.

${ }^{25}$ Edited in Steele 1922, 72-80.

${ }^{26}$ Last edited by Pedersen 1983, 174-201.

${ }^{27}$ The various treatises are listed in Thomson 1976, 107-112, with reference to the manuscripts and the secondary literature.

${ }^{28}$ Edited in Busard 1968.
} 
The maestri d'abbaco in Italy, the Rechenmeister in Germany and similar teachers in other countries, who taught in the vernacular, were ultimately dependent upon these standard Latin textbooks.

\section{Al-Khwārizmī's Treatise on Arithmetic}

Al-Khwārizmī's arithmetical work is the oldest Arabic work on Indian arithmetic of which we have detailed knowledge. Knowledge of arithmetic procedures undoubtedly existed among the Arabic-speaking peoples before his time; and it is also possible that written texts on the subject earlier than his were available. But unfortunately we have no certain knowledge of either the procedures or the texts. The treatise was written ca. 825, about 130 years earlier than al-Uqlīdisī’s Fusūl, the oldest extant work in Arabic on the subject.

Since no Arabic manuscript of al-Khwārizmī’s work is known, the work must be studied in the Latin texts which were based on the translation, now lost, which was made in the twelfth century. As mentioned above, there was an early reworking of the translation which is referred to here as DA. Of this text there are two manuscripts. One of them, Cambridge, University Library, Ii. 6.5, (hereafter called C), has been known for some time. It has been edited three times, ${ }^{29}$ published in facsimile three times $^{30}$ and translated into Russian, ${ }^{31}$ English $^{32}$ and French. ${ }^{33}$ Manuscript $\mathrm{C}$ is apparently of the thirteenth century and was at one time in the monastery of Bury St. Edmunds. It contains on ff. $104 \mathrm{r}-111 \mathrm{v}$ the text of DA, but only a little more than half of the text is present, because the last folios have been lost.

Until recently the existence of a second manuscript has remained unnoticed. In fact, there is a copy of DA in New York, Hispanic Society of America, HC 397/726, ff. $17 \mathrm{r}-24 \mathrm{v}$ (hereafter called N). ${ }^{34}$ It was written in Spain, probably in the thirteenth century. Up to the second half of the eighteenth century it belonged to the library of the Universidad Complutense at Alcalá de Henares. Unlike the copy in C, the manuscript is complete. In my book the text of manuscript $\mathrm{N}$ is edited for the first time, with parallel German translation. ${ }^{35}$ In order to allow a comparison between $\mathrm{N}$ and $\mathrm{C}$, the text of $\mathrm{C}$ is also edited parallel to $\mathrm{N}$; here a few mistakes in the earlier editions have been corrected. Manuscript $\mathrm{N}$ is reproduced in facsimile at the end of the book (Folkerts 1997).

\footnotetext{
${ }^{29}$ Boncompagni 1857, Vogel 1963, Allard 1992, 1-22.

${ }^{30}$ Vogel 1963, Juschkewitsch 1964b, Juschkewitsch 1983, 185-202.

${ }^{31}$ Kopelevič and Juškewič 1983.

${ }^{32}$ Crossley and Henry 1990.

${ }^{33}$ Allard 1992, 1-22.

${ }^{34}$ For a description of the content, see Folkerts 1997, 19-23. The description in Faulhaber 1983 is misleading for this item in the codex.

${ }^{35}$ Folkerts 1997, 28-107.
} 
With the discovery of manuscript $\mathrm{N}$ a more exact study of al-Khwārizmī's work has become possible. Formerly only guesses could be made about a large part of the text on the basis of the redactions LY, LA, and LP. Before discussing this further, we should consider how MS N and C are related to each other. In the part of the text common to the two manuscripts the wording is sometimes different. In the first chapters the differences are small, but they become greater later on. There are striking differences in chapters 3 and 10.1; it is almost as if the two manuscripts followed two different translations in some passages. But on the whole the differences lie in small points of style and do not affect the content. In most cases the wording in $\mathrm{N}$ is preferable to that in $\mathrm{C}$ : it is more detailed and more accurate. $\mathrm{C}$ contains several mistakes not present in $\mathrm{N}$; some of the superior $\mathrm{N}$ readings could not reasonably be supposed to be the result of scribal correction. Examples of such mistakes are the error in $\mathrm{C}$ in the rule for the resultant place in the multiplication of sexagesimal fractions (chapter 8.1) and the confusion of the terms minuta and secunda (chapters 10.3 and 10.4). In $\mathrm{N}$ there are chapter headings and diagrams with numerical examples, none of which appear in $\mathrm{C}$. But this does not mean that $\mathrm{N}$ has the original wording of the translation. In fact, both $\mathrm{N}$ and $\mathrm{C}$ appear to represent different stages in the reworking of the Latin translation. Nonetheless, $\mathrm{N}$ seems to be nearer the original translation than $\mathrm{C}$. This fits well with the observation that $\mathrm{N}$ was written in Spain, whereas C was written in England.

Despite all differences, therefore, it seems likely that $\mathrm{N}$ and $\mathrm{C}$ both represent a common source (DA). Sometimes this common source can be reconstructed. But the differences between the two manuscripts prevent this in many places. The date of DA can be estimated from the dates of the two manuscripts (thirteenth century) and of the translation from the Arabic (twelfth century; see below).

A natural question is: what relation has DA to the original translation? Any answer must be based on the readings of $\mathrm{N}$ and $\mathrm{C}$ and on equivalent passages in the twelfthcentury derivative texts LY and LA/LP.

In the parts common to $\mathrm{N}$ and $\mathrm{C}$ there are sections in which essentially western ideas are present and in which there are no Arabisms. For example, the discussion of unity (chapter 1.3) is probably to be ascribed to a later redactor. In some passages the text has clearly been "latinized." On the other hand there are many constructions and technical terms which unambiguously show their Arabic origin, no doubt alKhwārizmī's text. If we compare the complete text DA - as given in $\mathrm{N}-$ with the derivative texts LA/LP and LY, we find that the content is essentially the same. It is almost certain that this was the material of the translation. Style and terminology indicate that $\mathrm{N}$ - despite some reworking and additions - to a large extent reflects the wording of the Latin translation.

With the help of $\mathrm{N}$ we are for the first time in a position to reconstruct the part lost in $\mathrm{C}$ - the part dealing with division and root extraction - and thus to establish the whole of al-Khwārizmī's original text. In the part missing in $\mathrm{C}$ the derivative texts in LY and LA/LP are unreliable, being greatly expanded and otherwise reworked. 
As for the identity of the translator, there are only the slightest indications. Nonetheless, several translators have been suggested by historians of mathematics, always without reason: Adelard of Bath, Hermann of Carinthia, and Gerard of Cremona. No names are mentioned in MS N and C, and any suggestion must be the result of deduction or speculation. Hermann of Carinthia is certainly very unlikely: whereas the al-Khwārizmī text, in the parts that we may be fairly sure represent the words of the author, indicates a fairly literal rendering from the Arabic - with Arabisms and generally stiff Latinity -, Hermann's translating style is notoriously free. The case for Gerard is distinctly better, but by no means free of objection. For the derivative text LY has been dated to before 1143, and this has generally been considered as too early for Gerard, whose activity as translator in Toledo falls rather into the second half of the twelfth century. But the date 1143 is by no means certain. Further, the wording of al-Khwārizmī's quotation of his own Algebra in the text of DA (chapter 4.1) is remarkably similar to Gerard's wording in his translation of the Algebra. If Gerard was not the translator, then the names of Adelard of Bath and Robert of Chester come to mind. It certainly appears that the translation was made in Spain. For the scribe of MS N (or of an "ancestor" of $N$ ) on numerous occasions mistook the Roman numeral $X L$ for $X-$ a strong indication that its exemplar was written in Visigothic script. Furthermore, the form of the Hindu-Arabic numerals in $\mathrm{N}$ is similar to the form of those in the Codex Vigilanus and Codex Emilianus. But this does not bring us to any conclusions as to the translator.

The contents of al-Khwārizmī's Arithmetic may be reconstructed from MSS N and C. It is clear that this work was not a translation of some Indian text, but a compilation of material of Indian origin. The main topics are: form of the numerals and how numbers were written in the decimal place-value system (chapter 1); the six fundamental operations with integers (addition, subtraction, halving, doubling, multiplying, dividing; chapters 2-7); operations with fractions (multiplication, division, notation, addition, subtraction, doubling, halving; chapters 8-12); extraction of square roots of integers and of fractions (chapters 13-19).

The title of the Arabic original cannot be deduced from the Latin reworkings. In MS N the heading runs: Incipit arismethica Alchoarismi; in $\mathrm{C}$ there is no heading. From Arabic commentaries of al-Khwārizmī's Arithmetic mentioned in the Fihrist it seems that the title was: Kitāb fī'l-jam wa 'l-tafrīq (Book on gathering [collectio = addition] and separation $[$ dispersio $=$ subtraction] $)$.

\section{Contents of DA ${ }^{36}$}

Chapter 1: How numbers are written in the decimal place-value system

$<1.1>$ Praise to God. The treatise intends to explain the Indian method of calculation (numerus, Arabic hisāb) with nine digits (littere) with which any number

\footnotetext{
${ }^{36}$ The numbering of the chapters and sections (in angle brackets) corresponds with that of Folkerts 1997.
} 
can be easily represented. With these digits arithmetic, i.e. multiplication, division, addition and subtraction, may be simplified. The praise to God and the introductory passages are typically Arabic.

$<1.2>$ The Indian procedure with numerals is to be demonstrated so that the writing of numbers and operations with them become easier.

$<1.3>$ How the forms of the 9 digits are to be described. Here and in the following text in $\mathrm{C}$ only the digits $1,2,3,5$ and 0 appear, but in $\mathrm{N}$ all nine and the zero are present. They are clearly in the West-Arabic tradition. The forms of 1, 2 and 3 in $\mathrm{N}$ are very similar to those in the Codex Vigilanus; digits 4 to 9 are reminiscent of the form on the abacus in the Gerbert tradition. A somewhat changed form of the 4 is found in the 16-place number in section 1.8. The zero is a circle, a little smaller than the other numerals.

There are differences in the forms of the fifth, sixth, seventh, and eighth symbols. If this passage was in al-Khwārizmī's Arabic text, it referred to differences in form within the East-Arabic tradition, to which al-Baghdādī also refers in the case of 2, 3, and 8 . It is also possible that the "fifth" to the "eighth" symbols mean the numerals $5,4,3$, and 2 , since in the Latin text the nine numerals are written in order from right to left (copying the Arabic). It all depends on what the translator understood and in which direction he counted.

There follows a section on the nature of "one." At the beginning of his extended discussion the author says that he has shown in his own Algebra (liber algebr et almucabalah) that any number is composed of "ones." This and two later citations (in chapters 4.1 and 15), which indeed find confirmation in the transmitted text, show that the Algebra was written before the Arithmetic. This discussion of "one" corresponds to the Greek concept of number, according to which "one" is not a number, but the origin of numbers. The remainder of this chapter has the appearance of an addition by some Latin redactor: "another work on arithmetic" (which might be Boethius' Arithmetic) is mentioned, and chapter 1.3 ends with the words: Redeamus ad librum.

$<1.4>$ The decimal structure of the integers: by the doubling, tripling ..., multiplying by 9, of "one" the units are obtained; by the doubling etc. of "ten" the tens are obtained; and so on ad infinitum. All numbers that may be expressed in words can be expressed by means of the nine digits. The "zero" is not mentioned here. We note that the author mentions units, tens, hundreds, and thousands and that in Arabic there are words for these, and not for higher, categories; to express other - composed or larger - numbers, these words must be used in combination or derivation.

$<1.5>$ After these preparatory remarks the author explains the place-value principle which the Indians had worked out (operati sunt). First the central ideas of decimal place and of the zero are introduced. The term for (decimal) place is differentia, which is consistently used in $\mathrm{N}$; in $\mathrm{C}$ both differentia and mansio (remaining, stay, dwelling) are used. It is not clear of which Arabic word differentia is a translation; in early Arabic texts either martaba (pl. marätib) or rutba is found. On the other hand, mansio is certainly a translation of the Arabic manzila (pl. manāzil). 
It is shown in detail what units, tens, hundreds, thousands and ten-thousands are. According to the place-value system, "one," when put in the next higher place, has the value "ten"; a digit meaning "ten" in the tens means "one" in the units; and so on. This principle is differently expressed in $\mathrm{N}$ and C, Arabic practice of writing from right to left being mirrored in $\mathrm{N}$ and Latin direction of writing being accommodated in $\mathrm{C}$. The counting of the places begins on the right.

When a "one" is in the second place, i.e. means "ten," a sign in the first place (from the right) is needed to show that it means ten: a sign is put in the first place to show that it is empty. It is in the form of a small $o$. In the entire text the zero is represented by the word circulus (Arabic: dā'ira). The Indians called the zero śūnya (i.e. empty); the Arabic translation of this word is as-sifr, from which the Latins had the term cifra from the twelfth century on. The word cifra is also found in a reworking of a translation of al-Khwārizmī's astronomical tables. Whether al-Khwārizmī used the term aș-sifr in either the Arithmetic or in his tables, we cannot tell from the Latin texts available to us.

$<1.6>$ There follows a detailed description of how hundreds and thousands are written: two or three (resp.) zeros must be written before (i.e. on the right of) the digits, if these places are not occupied by digits (i.e. 1 to 9). In other cases the appropriate digit must be put in its appropriate place (in ea differentia que sibi debetur). The examples 11 and 325 are described in detail.

$<1.7>$ In this section the carrying procedure is described in detail: what is done when in any place ten or more units are assembled (collecti fuerint). Various special cases are treated: when just 10 are assembled, the digit in that place must be substituted by a zero; when a "large" number (typically 9) is in some place and 1 is carried from the previous, then two carrying procedures must be done. The description is, by modern standards, lengthy and repetitive.

$<1.8>$ The chapter on how numbers are written ends with a section on writing large numbers and pronouncing them in words. The author gives the names for the places from the first to the thirteenth (i.e. $10^{0}$ to $10^{12}$ ). Since the Arabs have words for numbers only up to a thousand, the higher numbers must be expressed in terms of these; e.g. $10^{12}$ is expressed as "a thousandfold thousand thousand thousand." From a thousand million on adverbs such as milies or phrases such as milia . . tribus vicibus are used.

$1,180,703,051,492,863$ is the example used for writing large numbers. This number is written incorrectly in $\mathrm{N}$ and does not appear in $\mathrm{C}$ at all. To facilitate reading, the number is divided into groups of three digits. It is stated that numbers are to be pronounced while being written. This practice is mentioned in numerous texts extant in Arabic.

\section{Chapter 2: Addition and subtraction of integers}

$<2.1>$ The general procedure of addition is described. On what object calculations are performed is not stated. But we know from an aside in the chapter 
on multiplication - and from extant Arabic texts - that a board (tabula, takht) was normally used. It was covered with dust, sand, wax, or white powder. On this the numbers were written and in the process of calculation digits were replaced by others or totally erased (Arabic: mah $\vec{a}$ ). In addition, subtraction and multiplication one of the numbers in the calculation was written above the other and its digits were successively replaced by those of the resultant number: at the end of the operation the number written at the top of the calculation was completely replaced by the result. In the addition of two numbers one was placed above the other so that the various decimal places corresponded. The digits in the individual places are to be added and carrying is performed, if necessary. The description is short, and no example is given. In this chapter it is not explicitly stated if one begins at the right or the left side.

$<2.2>$ In subtraction the minuend is written above the subtrahend so that the various places match. In each place the lower number is taken from the upper. The case in which the upper digit is smaller than the lower and the case in which the upper digit is zero are treated in great detail: in such cases a unit must be taken from the next higher place in the upper number and changed into ten units of the current place. The operation begins with the highest place.

$<2.3>$ To explain the general rules of subtraction, $\mathrm{N}$ announces two examples and $\mathrm{C}$ three. The first example is: $6422-3211=3211$. The individual steps of the calculation are expressed only in words.

$<2.4>$ The second example of subtraction is given to illustrate what happens when "nothing" (nichil, C) or "little" (parum, N) is left in the (minuend's) places. In $\mathrm{C}$ in the example $1144-144$ only the problem is given, expressed in words. No scheme (i.e. a direct representation of the numbers as they are to be written) is given, the subtraction is not described, and the result is not given. In $\mathrm{N}$ there is a slightly different example, $1444-144$. The scheme is given, the individual steps are described in great detail, and the result is correct. Here and often elsewhere in $\mathrm{N}$ the number 40 is incorrectly given as "ten" $(X)$. This is a strong indication that in a chain of copies of which $\mathrm{N}$ was the end-product there was a manuscript written in Visigothic script: only in this script does the number $X L$ resemble the $X$ (it is an $X$ with a hook on the top right corner).

\section{Chapter 3: Doubling and halving}

Halving is treated before doubling. One begins with the lowest decimal place. If it is odd, one halves the even number (i.e. the greatest even number less than the odd number in question) and the half of the remaining 1 is written as 30 (i.e. $\frac{30}{60}$, which is a half in sexagesimal notation) underneath the half of the even number. In all other places an even digit is likewise halved, but in the case of an odd digit the odd 1 is taken to the next lower place as a 5. Doubling is described in only one sentence: one starts with the highest place. If more than 10 result in any one place, ten is carried as a 1 to the next higher place. Examples are not given for either operation. 


\section{Chapter 4: Multiplication of integers}

$<4.1>$ The author starts with a self-quotation from the Algebra for a general meaning of multiplication: when a number is multiplied by another, one of them is "repeated" (duplicari) according to the number of units in the other. To multiply with Indian numerals the calculator must know the multiplication table $(1 \times 1$ till $9 \times 9)$ by heart. In some Arabic and Latin texts a multiplication table is given, but there is none in DA.

Rules follow for writing down the numbers to be multiplied: they are written in two lines, the highest place of the upper (which is the multiplier) being placed above the lowest place of the lower (the multiplicand).

$<4.2>$ To explain the individual steps of multiplication, the example $2326 \times 214$ is presented. The 4 of the multiplicand 214 is written under the first 2 of the multiplier 2326. The digit which is in the highest place of the multiplier multiplies successively the individual digits of the multiplicand, beginning with its highest place, the result being put directly above the multiplicand (the first digit of the multiplier is replaced in this process by the last digit of the partial result). After the highest place of the multiplier has been dealt with, the multiplicand is shifted one place to the right, and the procedure is repeated with the next digit of the multiplier (3), the partial results being added. Then the multiplicand is shifted again and the process repeated, and so on, until the digits of the multiplier are exhausted.

$<4.3>$ In this section special cases are treated, in particular cases in multiplication by zero. In the text there is the equivalent of $0 \times n=n \times 0=0$. Then the remainder of the above example is given. At the end the result is 497764 .

\section{Chapter 5: Checking multiplication and doubling by casting out nines}

The casting out of nines is a check to see whether the multiplication or doubling has been correctly carried out. It is applied in DA, but is not given a special name (only probatio). The excess of nines is not found by adding the digits, but by finding the remainder on division by 9. The Latin expression divide numerum per novem novem is evidently taken from the Arabic. In the case of multiplication the procedure is applied to the multiplier and multiplicand; the two excesses are multiplied; if the result is the same as the excess of nines of the product, the product is considered correct. The author did not know that the test is a necessary, but not sufficient condition.

It is noteworthy that in DA the casting out of nines is mentioned only in this place. For division in chapters 10.4 and 10.5 another kind of test is given: the dividend is compared with the product of divisor and result. For the other operations no test is given.

\section{Chapter 6: Division of integers. General remarks}

$<6>$ Chapter 6 treats the general procedures of division of integers; examples follow in chapter 7 . The highest place of the divisor is placed under the highest place of the dividend if the digit of the divisor is smaller; if not, the divisor is shifted one 
place to the right. The two digits are divided, the result (without fractions) being placed over the dividend, vertically aligned with the last place of the divisor. By this result the successive digits of the divisor are multiplied (starting from the left), the partial products being subtracted from the corresponding digits of the dividend. The dividend has now been changed in some of its digits, and the new number takes the part of the dividend in the next part of the process. This begins by shifting the divisor one place to the right, and so on. In this way the digits of the quotient gradually appear over the (altered) dividend. The result of the division is described in DA what "will be that which corresponds to one" (ipsum erit, quod debetur uni). The idea evidently comes from proportions: the division $a \div b=q$ is equivalent to the proportion $a: b=q: 1$. If there is a remainder, it is a part which comes from the dividend (erunt partes unius ex numero quem dividis). It must be less than the divisor, for otherwise a mistake has been made.

\section{Chapter 7: Division of integers. Examples}

$<7.1>$ After saying that division is the inverse of multiplication, the author gives an example which is described in great detail: $46468 \div 324=143 \frac{136}{324}$. Only the first and last configurations are illustrated by schemes, but all steps are given in words. This procedure can be followed, but with some difficulty.

$<7.2>$ In a second example a number with several places, some of them zeros, is divided by a single-digit number: $1800 \div 9$. The author says that the work of division is shortened when there are zeros in the dividend or produced by the division procedure.

\section{Chapter 8: Multiplication of fractions}

$<8.1>$ In chapters 8 to 12 calculation with fractions and mixed numbers (integers mixed with fractions) is treated: first multiplication (chapters 8-9); then division (chapter 10); only then notation, addition, subtraction, halving and doubling (chapter 11); and finally multiplication and division of common fractions (chapter 12). In DA, calculation with common fractions and with sexagesimal fractions are not properly distinguished, but the attempt is made to show that calculation with all kinds of fractions follows the same rules.

There are innumerable names for the fractions, e.g. "half," "third." Some unit fractions and sexagesimal fractions are mentioned, but the author does not know a general word for unit fraction or for sexagesimal fraction. Sexagesimal fractions were used by the Indians. In sexagesimal subdivision there are "places" (differentie) as in the decimal representation of integers: integers or "degrees" are in the first place, "minutes" in the second, "seconds" in the third, etc. until the ninth and tenth places. The introductory sentences in DA on fractions make clear that common fractions, particularly unit fractions, were known in the daily life of the Arabs as in other cultures, whereas sexagesimal fractions belonged to another, "scientific," world. 
After the general remarks about fractions it is explained how the place of the result of a multiplication of two sexagesimal fractions can be determined. When an integer and a fraction is multiplied, then the kind (genus) of fraction is not changed. For instance: $2^{\circ} \times 2^{\prime}=4^{\prime} ; 3^{\circ} \times 6^{\prime \prime \prime}=18^{\prime \prime \prime}$. When fractions are multiplied, their places are "collected" (colligis utrasque differentias), i.e. "added," and the sum is the place of the product. The author applies this principle to multiplying minutes by minutes, seconds by seconds, etc. Two examples are given: $6^{\prime} \times 7^{\prime}=42^{\prime \prime}$ and $7^{\prime \prime} \times 9^{\prime}=63^{\prime \prime \prime}=1^{\prime \prime} 3^{\prime \prime \prime}$.

$<8.2>$ This section gives an example of multiplying mixed numbers (integers mixed with common fractions). The common fractions are converted into sexagesimal fractions, and the calculation is given as above. The example is: $1 \frac{1}{2} \times 1 \frac{1}{2}$. The individual steps are: $1 \frac{1}{2} \times 1 \frac{1}{2}=90^{\prime} \times 90^{\prime}=8100^{\prime \prime}=135^{\prime}=2^{\circ} 15^{\prime}=2 \frac{1}{4}$. The fractions in each number are written as sexagesimal fractions; then the integral part is expressed in the same unit and added to the fractional part; then they are multiplied decimally. The result is a sexagesimal fraction whose place is determined by the rules of chapter 8.1. It is successively divided by 60 each time reducing the rank of the sexagesimal fraction. Finally the sexagesimal fraction is reconverted to a common fraction. Thus common fractions are here multiplied only after conversion to sexagesimal fractions. This demonstrates the dominating position of sexagesimal fractions over common fractions. Since every factor is expressed in terms of the lowest denomination present in the number after conversion into sexagesimals, only integers must be multiplied, and for this the rules have already been given.

\section{Chapter 9: Multiplication of fractions when they comprise minutes and seconds}

In this chapter an example is given to explain how relatively complicated (sexagesimal) fractions, comprising minutes and seconds, are multiplied. The procedure has already been explained in the previous chapter: one converts each of the two numbers to be multiplied into units of the lowest denomination that it contains, the two resulting integers are multiplied, and the product is reconverted to sexagesimal-fraction form by successive divisions by 60 . The example is: $2^{\circ} 45^{\prime} \times 3^{\circ} 10^{\prime} 0^{\prime \prime}=8^{\circ} 43^{\prime} 52^{\prime \prime} 30^{\prime \prime \prime}$.

At the end there is a remark that there is a shorter method. Presumably the direct multiplication of the constituent sexagesimal places, the application of the rule determining the place of the result and the addition of the partial results is meant. This procedure would require a multiplication table of $1 \times 1$ up to $59 \times 59$. Such tables exist in extant Arabic texts, but not in DA.

Chapter 10: Division of fractions of any kind: general remarks; examples of divison of sexagesimal fractions; check

$<10.1>$ Chapter 10 treats the division of fractions. Since no distinction is made between sexagesimal fractions and common fractions, it could be assumed that the 
following procedures are valid for all fractions. What actually follows are rules for division of sexagesimal fractions (but see chapter 10.2); the division of common fractions is left until chapter 12.

First the general rule is given for dividing fractions or mixed numbers (i.e. numbers mixed of integers and fractions): each of the numbers is reduced to units of the lowest denomination present in either number; the division between the resulting integers is made; the result is in gradus, i.e. whole numbers, because the numbers that were divided are of the same rank (unius generis).

$<10.2>$ To explain the rule, three examples are given. The first is: $\frac{15}{3} \div \frac{6}{3}=2 \frac{1}{2}$. It has been supposed that the original text ran 15 thirds divided by 6 thirds. This would maintain a sexagesimal treatment in this part of the text.

$<10.3>$ The second example illustrates the case in which the dividend is smaller than the divisor: $10^{\prime \prime} \div 5^{\prime}=10^{\prime \prime} \div 300^{\prime \prime}=600^{\prime \prime \prime} \div 300^{\prime \prime}=2^{\prime}$.

$<10.4>$ To verify the division, a check can be performed: the quotient is multiplied by the divisor, and the result should be the dividend. Two examples of this are given: for the divisions $50 \div 10=5$ and $10^{\prime \prime} \div 5^{\prime}=2^{\prime}$.

$<10.5>$ The third example is: $10^{\prime} \div 5^{\prime \prime \prime}$. The procedure is: $10^{\prime} \div 5^{\prime \prime \prime}=36000^{\prime \prime \prime} \div 5^{\prime \prime \prime}=7200^{\circ}$. The check is $7200^{\circ} \times 5^{\prime \prime \prime}=36000^{\prime \prime \prime}=600^{\prime \prime}=10^{\prime}$.

Chapter 11: How numbers made up of integers and sexagesimal fractions are written; arithmetical operations with them: addition, subtraction, halving and doubling

$<11.1>$ The chapter begins with the way of writing (constituere) mixed numbers: the integers and their sexagesimal parts are written one under the other. If there is no entry in a sexagesimal place, two zeros are written. An example (in modern notation) is: $12^{\circ} 30^{\prime} 45^{\prime \prime} 0^{\prime \prime \prime} 50^{\prime \prime \prime \prime}$.

$<11.2>$ In this section addition is treated, but the text is short and unclear. It is not stated how the two numbers are to be placed on the board, and a word for "addition" is not explicitly mentioned. It is mentioned, however, that when more than 60 units are accumulated in one place, 60 of them are carried as 1 to the next place.

$<11.3>$ When one sexagesimal fraction is subtracted from another, the procedure begins with the highest place. From each place of the minuend the corresponding place of the subtrahend is subtracted. When some place of the minuend is less than the corresponding place of the subtrahend, 1 is borrowed from the next-highest place and becomes 60 in the place of the subtrahend, so that the subtraction can be performed. No example is given; and because of the clumsy verbal expression, the text is hard to understand.

$<11.4>$ In doubling sexagesimals the rule is to begin with the highest place. When more than 60 is thereby accumulated in any place, the excess over 60 is written down, and 1 is added to the next-highest place. Halving sexagesimals, by contrast, begins with the lowest place. There are no examples. We note that doubling is here treated before halving, though in chapter 3 it was the other way round. 


\section{Chapter 12: Multiplication and division of common fractions}

$<12.1>$ Until now the only fractions with which calculations were made were sexagesimal fractions. Now multiplication and division with common fractions are explained. The procedure is analogous to the multiplication with sexagesimal fractions: the fractions are reduced to units of the "lowest denomination" (ex genere inferioris differentie). Then these units are multiplied. Finally the result is divided out to obtain integers.

$<12.2>$ To explain the procedure, two examples are given. The first is: $\frac{3}{7} \times \frac{4}{9}$. According to DA, the seventh and the ninth should be considered "as minutes" and their product "as seconds." To find out whether there are integers and, if so, how many, the result of the multiplication must be divided by the product (in this case: seventh times ninths). The author gives the result of this example as $\frac{12}{63}$, i.e. "12 parts of 63 parts of one." In $\mathrm{N}$, but not in $\mathrm{C}$, there is a long explanation of the individual steps in the example. The procedure involves several unnecessary operations.

$<12.3>$ The second example is $3 \frac{1}{2} \times 8 \frac{3}{11}$. In contrast to the previous problem, the presentation is clear. The two mixed numbers are written vertically one beside the other, so that the integers are written at the top, then the numerators and then the denominators. The integers and the fractions are converted into units of the corresponding denominator. Now the numerators are multiplied together, the denominators are multiplied together, and one product is divided by the other. Thus: $7 \times 91=637 ; 2 \times 11=22 \Rightarrow 637 \div 22=28 \frac{21}{22}$.

In the middle of the calculation the text in $\mathrm{C}$ breaks off, so that the subsequent text until the end of the whole work is transmitted only in $\mathrm{N}$.

$<12.4>$ To divide common fractions the rule is: convert both fractions to fractions of the same sort (i.e. with the same denominator) and divide "one by the other" (i.e. the new numerators). The result is an integer. The procedure is explained by the example $20 \frac{2}{13} \div 3 \frac{1}{3}$. Since neither of the terms "numerator" and "denominator" are mentioned, the presentation is not easy.

\section{Chapter 13: General statements about roots}

$<13.1>$ With chapter 13 the last part of the book begins. It deals exclusively with the extraction of roots. Chapter 13 treats the general properties of (square) roots (radix; Arabic jidhr).

Without defining the term "root," the author states that, when two numbers - be they integers or fractions - are equal, their product "has a root," i.e. is a square number. This simple result is justified by observing that in this case the multiplication of one number by another is equal to the multiplication of a number by itself. Then comes the theorem: if $a$ and $b$ are square numbers, then so is $a \times b$. There are no examples in this section.

$<13.2>$ The next theorem runs: for any numbers $a$ and $b$, when $a \div b$ is a square number, then $a \times b$ is also a square number. The example with $a=18$ and $b=8$ is given. Then $18 \div 8=2 \frac{1}{4}=\left(1 \frac{1}{2}\right)^{2}$, a square, and $18 \times 8=144=12^{2}$, also a square. It is 
stated further that $b \div a$ is also a square number, for $8 \div 18=\frac{4}{9}=\left(\frac{2}{3}\right)^{2}$. Another example, with $a=8$ and $b=2$ is mentioned, but not given in detail.

$<13.3>$ In this section the author treats a question of some importance for the extraction of roots: from which decimal places can roots be extracted? Expressed in modern terms, he reaches the result that $10^{n}$ has a square root if, and only if, $n$ is even. The principles of the Indian decimal place system are first repeated (cf. chapter 1). Then it is asked whether the units, tens, hundreds and thousands have roots or not: one has a root, i.e. $1 ; 10$ has no root; 100 has a root, i.e. 10; 1000 has no root, because it is equal to $100 \times 10$, i.e. a square multiplied by a non-square. Finally the author states that $1,10,100 \ldots$ are alternately squares and non-squares, i.e. the places with odd rank have square roots - and those with even rank have not.

$<13.4>$ Next comes the question: from which fractions can roots be extracted? It is shown that sexagesimal fractions of odd rank (i.e. minutes, thirds, fifths . . .) have no square roots, but those of even rank (i.e. seconds, fourths, sixths . . .) do have. The author treats common fractions analogously: he considers a class of "first fractions" (prime fractiones) which have no root (i.e. fractions whose denominators have no root); "second fractions" (secunde fractiones, i.e. first fractions multiplied by themselves) do have roots; "third fractions" (fractions of the tertia differentia, i.e. first fractions multiplied by themselves twice) have no roots, etc. We should note here that the author tries again to force common fractions into the rules valid for sexagesimal fractions.

\section{Chapter 14: General procedure for extracting square roots}

This chapter gives in detail the procedure for finding the square root of any integer; an example is not given here, but only in chapter 16. First the decimal place-value system is yet again described, this time with a reference to the beginning of the work. Then comes a repetition of the statement of the previous chapter, that the decimal places of odd rank have roots and those of even rank have none. The procedure begins by counting the decimal places in the number whose root is required: if the highest place is of odd rank, then you "work in it" (operaberis in ea); if it is of even rank, then you "do not work in it," but go to the next place (to the right). This means, of course, that the places are counted from right to left and marked in pairs, as is done today. The greatest square number less than or equal to the number (or pair of numbers) in the left-most group must now be found and subtracted from it; the difference is written in the place of the group being operated on. The root of the square number is the highest place of the square root sought. Then this partial result is doubled and written one place to the right. The greatest single digit, the next place of the result, is now sought such that when it is written alongside the doubled partial result to form one number, and when this number is multiplied by the digit, the product is less than the number formed by the first two groups on the left side. This procedure is continued, until there is no remainder or the remainder is less than the double of the result so far calculated. If there is no remainder, the result is the exact square root (radix integra). If there is a remainder, an approximate root is obtained by adding to the 
partial result a fraction comprising the remainder divided by twice the partial result. This corresponds to the modern formula $\sqrt{N}=\sqrt{a^{2}+r} \approx a+\frac{r}{2 a}$. The very abstract presentation is made easier by the example in chapter 16.

Chapter 15: Theoretical questions about the extraction of square roots; the reason why the partial results need to be doubled

This chapter complements the previous chapter and is apparently intended to justify the doubling of the partial results in the procedure for extracting roots. The author refers to "another book by himself" (patefeci in alio libro meo: evidently his Algebra) for the general rule that when two numbers both with nodi and unitates (i.e. numbers with two decimal places) are to be multiplied, four separate multiplications must be made. In modern notation: $(10 a+b) \times(10 c+d)=10 a \times 10 c+10 b c+$ $10 a d+b d$. A similar rule for squaring is evidently implied, so that the reason for doubling of the partial result becomes clear. The text in DA is sometimes not very clear and perhaps has suffered at the hands of copyists.

\section{Chapter 16: Examples of extracting the square root of integers}

$<16.1>$ According to the procedure abstractly described in chapter 14, $\sqrt{5625}=75$ is now calculated in detail.

$<16.2>$ This section treats the special case in which a pair of places are both zero. No example is given.

$<16.3>$ Another, "shortened," procedure (adbreviatio) is explained for finding the roots of numbers ending in a series of zeros: half the number of zeros is put at the end of the root of the number shorn of its zeros. In this case one does not need to go through the procedure of doubling etc. as in the general case. The example of $\sqrt{10000}$ is given, the result being 100 .

\section{Chapter 17: Calculation of the roots of fractions}

$<17.1>$ To find the root of a fraction or of a mixed number, the first step is to reduce the number to the lowest place of the fractional part. When this place is such that "a root exists" (i.e. in the case of sexagesimal fractions: seconds, fourths, ...), then the procedure of chapter 16 is applied, and the result is reconverted to larger units. When the lowest place "has no root" (i.e. in the case of sexagesimal fractions: minutes, thirds, fifths, ... .), the number must be reduced to units of a place which has a root; and again the root is found and then reconverted to larger units. The procedure is made the more exact (propius veritati) the lower the place ("having a root") to which it is reduced.

$<17.2>$ To explain this procedure, two examples are given. The first is: $\sqrt{2}$. The 2 is converted into seconds; if the 2 were converted into fourths or sixths, the result would be still more exact. Thus $\sqrt{2}$ is found as $\sqrt{7200}^{\prime}=84^{\prime}+$ remainder $=1$ integer $24^{\prime}+$ remainder. (A better approximation for $\sqrt{2}$ is found in chapter 19.2.) 
$<17.3>$ The second example is of a root of a mixed number comprising integers and common fractions: $\sqrt{2+\frac{1}{3}+\frac{1}{13}}$. The number must be reduced to units "of one species" (ex uno genere); in modern terms, on the product of the denominators as denominator. Then numerator and denominator of the fraction must be multiplied by a number to make the denominator a square. Implicit here is the formula $\sqrt{\frac{a}{b}}=\frac{\sqrt{a b}}{b}$. The individual steps are:

$$
\begin{aligned}
\sqrt{2+\frac{1}{3}+\frac{1}{13}} & =\sqrt{\frac{78+13+3}{39}}=\sqrt{\frac{94}{39}}=\sqrt{\frac{94 \times 39}{39^{2}}}=\frac{\sqrt{3666}}{39} \\
& =\frac{60}{39}+\text { remainder }=1 \frac{21}{39}+\text { remainder. }
\end{aligned}
$$

To obtain a still more exact result, the fraction would have to be converted to "fourths," i.e. its numerator and denominator would be multiplied twice more by 39 (the denominator). Then the steps would be (in $\mathrm{N}$ there are some incorrect numbers):

$$
\frac{\sqrt{3666}}{39}=\frac{\sqrt{3666 \times 39^{2}}}{39^{2}}=\frac{\sqrt{5575986}}{39^{2}}=\frac{2361+\text { remainder }}{39^{2}}
$$

Chapter 18: On extracting square roots depending on what the Indians have established

There follows a chapter which, according to its title, did not belong directly to the Indian procedure (opus), but was somehow dependent on it; it is supposed to be easier and more exact (levius opere Indorum atque subtilius). The words sed ego extraxi illud secundum quod constituerunt Indi show unambiguously that this section is due to the author, al-Khwārizmī, himself, but depends on Indian procedures.

Al-Khwārizmī here demonstrates a method of improving the accuracy of root extraction: he adds an even number of zeros to the number whose root is to be extracted. After extraction the root is reduced in the rank of its decimal places by the appropriate number - half the number of zeros which were added to the original number. The following relation is implicit:

$$
\sqrt{\mathrm{N}}=\frac{1}{10^{k}} \sqrt{\mathrm{N} \times 10^{2 k}}
$$

The fractional part is re-expressed in sexagesimal fractions. The result is more exact the more zeros are added. The presentation is understandable, but clumsy. 
Chapter 19: Extraction of roots of integers or of mixed numbers (by adding zeros)

$<19.1>$ In this chapter the extraction of the roots of integers or mixed numbers (the fractional part being either a vulgar or sexagesimal fraction) is again treated. It is surprising that this topic comes up yet again, since it is amply treated in chapters 14-16 for integers and in chapter 17 for fractions. Indeed, nothing is essentially new in this chapter: in 19.1 the procedure of the previous chapter is repeated, and in 19.2 an example of it is presented.

The general procedure is first indicated: the elements of the mixed number are reduced to units of its lowest place; if this place is not one that "has a root," the number must be further reduced to the next-lower place. Now an even number of zeros can be placed at the end of the number (cf. chapter 18). After extracting the root the remainder is converted to sexagesimal fractions by repeated multiplication by 60 . The whole section could be greatly shortened or omitted entirely, since the general procedure has already been described in chapter 18 .

$<19.2>$ The procedure is demonstrated by the example $\sqrt{2}$. In this case, 6 zeros are added. The steps are:

$$
\begin{aligned}
\sqrt{2} & =\sqrt{\frac{2.000 .000}{10^{6}}}=\frac{1}{1000} \times \sqrt{2.000 .000}=\frac{1}{1000} \times[1414+\text { remainder }] \\
& \approx \frac{1}{1000} \times 1414=1(\text { unit })+\frac{414}{1000}=1+\left(\frac{414 \times 60}{1000}\right)^{\prime}=1+\frac{24840}{1000} \\
& =1+24^{\prime}+\left(\frac{840 \times 60}{1000}\right)^{\prime \prime}=1+24^{\prime}+\left(\frac{50400}{1000}\right)^{\prime \prime}=1+24^{\prime}+50^{\prime \prime}+\left(\frac{400 \times 60}{1000}\right)^{\prime \prime \prime} \\
& =1+24^{\prime}+50^{\prime \prime}+24^{\prime \prime \prime} .
\end{aligned}
$$

Thus by the use of the extra zeros a more exact result has been obtained for the same example than with the simpler procedure of chapter 17.2 , which only produces minutes.

With this example the text ends. There follows only the explicit with praise and thanks to God. Of this whole formula the original Arabic is easily understood: "It is finished (tamma, Finit) the book (al-kitāb, liber) with the help of God (bi-caun Alläh, cum dei adiutorio) and praise to Him (wa-hamdihi, et eius laude)".

If DA - as it may be deduced from manuscripts $\mathrm{N}$ and $\mathrm{C}-$ is compared with later Arabic texts on arithmetic, the following remarks may be made: 
- Very detailed, sometimes long-winded presentation

This applies, for instance, to the statements in chapter 1 on the decimal system, the representation of numbers, the idea of place (differentia) and the use of zeros in writing multiples of the powers of 10. Many things mentioned in this chapter are repeated in the chapter introducing fractions (13.3). - The zero receives special treatment not only in the first chapter, but also in one of the sections on extraction of roots (16.2). - The method of increasing the accuracy of root extraction by adding zeros to the number comes in chapter 18 and again immediately afterwards in chapter 19.1. - It is perhaps understandable that the properties of the zero should be described in more detail and perhaps more often than properties of the "common" digits, since the zero has the strange property of being at once "nothing" and at the same time having the power of increasing the value of a digit ten times.

\section{- Missing technical terms}

For several important terms in arithmetic there are no technical terms in DA; e.g. there are no proper terms for "minuend," "subtrahend," "multiplier," "multiplicand," "divisor," "dividend," "numerator," "denominator," "square number." Even for the zero there is no special expression (such as: ciffra found in other texts), only the description circulus. Because of the lack of technical terms the presentation of arithmetic operations becomes hard to understand - a good example is the multiplication and division of fractions in chapter 12 .

\section{- Inappropriate order of the material}

In chapter 1.7 things connected with addition are described, although addition is formally only described later. - In one place (chapter 3) doubling is treated after halving and in another (chapter 11.4) before halving. - Multiplication and division of fractions are treated in chapters $8-10$, i.e. before the notation of fractions (chapter 11).

\section{- Unclear or awkward presentation}

Often in the text there is a verbal description of a complex process without the "schemes" that would clarify the steps of the operation. Examples are: multiplication (chapter 4), division (chapter 7.1), multiplication of common fractions (chapter 12.1). - The discussion of fractions is often obscured by the forced analogy of common fractions and sexagesimal fractions: clearly the author had the idea that the rules for these two classes of fractions were the same; in chapter 8 he even tries to prove this. - An example of division of fractions (chapter 10.2) appears to be spoiled by the confusion of the common fraction "thirds" (tercie) with the sexagesimal "thirds" (tercia). - The description of the addition of sexagesimal fractions is very unclear; it is even not stated in the text that addition is being treated (chapter 11.2). - The pairing off of the digits in the initial stages of root extraction (chapter 14) is not clearly described. - Also obscure is the explanation of why doubling is necessary in the procedure for extraction of roots (chapter 15). - The example of $\sqrt{2}$ is given a second 
time (chapter 19.2; cf. chapter 17.2) without reference to the former, less accurate, calculation.

- Unclear understanding by the author or redactor

Some passages may be unclear because the author or redactor did not understand the matter. An example is the lack of justification of the different treatment of the odd 1 in the operation of halving (chapter 3) - sometimes 30 is added to the next-lower place and sometimes 5. - Further he tries, without success, to show that common fractions and sexagesimal fractions follow the same rules in extraction of square roots (chapter 13.4). - The notion of prime fractiones etc. remains unclear (chapter 13.4).

\section{- Old-fashioned presentation}

Some of the descriptions of arithmetic processes give the impression of having been written when these processes were new. An example is the presentation of the casting out of nines (chapter 5): the excess of nines is not found by adding the digits but by finding the remainder of the original number on division by 9 . (The passage is obscured by the apparently mixed term of divide per novem novem.) This check is applied to doubling and multiplication, but not to division - for which the lengthy check by multiplication is suggested (chapter 10.4). - The multiplication of common fractions is made unnecessarily complicated by the multiplication of the numerators with the corresponding denominators (chapter 12.2; only in manuscript $\mathrm{N}$ ).

Even if it is not certain whether all of these curiosities were in the translation from the Arabic or whether they crept in at a later stage, they all point in the same direction: that the text of DA represents a relatively early stage of the knowledge of Indian arithmetic. At such a time it was difficult to understand the content in detail, and many technical terms had not been coined. The presentation of the material in DA is not uniform: sometimes it is long-winded and sometimes so short as to be scarcely comprehensible. All this accords well with the fact that al-Khwārizmī wrote the text in a time in which the 'new arithmetic' was first introduced into the Arabicspeaking world. The suggestion of A. P. Youshkevitch, that al-Khwārizmī expressed himself clearly and that the oddities and inconsistencies of the Latin text were entirely due to a Latin redactor of the twelfth or thirteenth centuries, appears quite unjustified.

Not surprisingly, the texts on Indian arithmetic written after al-Khwārizmī’s time present the material more clearly. This is true for both Arabic and Western authors. The writings of al-Uqlīdisī, Kūshyār ibn Labbān and al-Baghdādī - all of them more than 100 years later than al-Khwārizmī - show that the knowledge taken over from the Indians was not only understood, but also developed. Inter alia, technical terms were introduced, procedures were found which simplified the calculations and the methods were more clearly explained. In the West, also, there were reworkings which show that the problems of understanding the material, found in DA, had been solved as early as the twelfth century: the derivative texts of LA/LP (which in one place 
explicitly cites Alchorismus, i.e. the text of the translation effectively present in DA) and LY have the same structure as DA, but have a developed terminology and present the new arithmetic in a clearer form - whether or not this is done in extended form (as in LA/LP) or in a short presentation (as in LY). It is easy to understand that these later texts or other simple compilations such as those of Johannes de Sacrobosco or Alexander de Villa Dei were much more popular than DA, which was closer to the original translation, but not so easy to understand. An indication of this is the existence of only two manuscripts of DA.

\section{References}

Allard, André. 1978. “A propos d'un algorisme latin de Frankenthal: une méthode de recherche." Janus 65:119-141.

Allard, André. 1991. "The Arabic origins and development of Latin algorisms in the twelfth century." Arabic Sciences and Philosophy 1:233-283.

Allard, André. 1992. Muhammad ibn Mūsā al-Khwārizmī: Le Calcul Indien (Algorismus). Histoire des textes, édition critique, traduction et commentaire des plus anciennes versions latines remaniées du XII e siècle. Paris: Albert Blanchard/Namur: Société des Etudes Classiques.

Beaujouan, Guy. 1948. “Étude paléographique sur la 'rotation' des chiffres et l'employ des apices du X ${ }^{\mathrm{e}}$ au XII ${ }^{\mathrm{e}}$ siècle." Revue d'histoire des sciences 1:301-313.

Bergmann, Werner. 1985. Innovationen im Quadrivium des 10. und 11. Jahrhunderts. Studien zur Einführung von Astrolab und Abakus im lateinischen Mittelalter. Stuttgart: Franz Steiner.

Boncompagni, Baldassarre. 1857. Trattati d'aritmetica. I. Algoritmi de numero Indorum. Rome: Tipografia delle scienze fisiche e matematiche.

Bose, D. M., S. N. Sen, B. V. Subbarayappa. 1971. A Concise History of Science in India. New Delhi: Indian National Science Academy.

Bubnov, Nicolaus. 1899. Gerberti postea Silvestri II papae Opera Mathematica (972-1003). Berlin: R. Friedländer u. Sohn.

Burnett, Charles. 1996. "Algorismi vel helcep decentior est diligentia: The Arithmetic of Adelard of Bath and his Circle.” In Mathematische Probleme im Mittelalter - der lateinische und arabische Sprachbereich, edited by Menso Folkerts, 221-332. Wiesbaden: Harrassowitz.

Busard, Hubert L. L. 1968. "Het rekenen met breuken in de middeleeuwen, in het bijzonder bij Johannes de Lineriis." In Mededelingen van de Koninklijke Vlaamse Academie voor Wetenschappen, Letteren en Schone Kunsten van België. Klasse der Wetenschappen. Jaargang 30, nr.7. Brussels.

Cantor, Moritz. 1865. "Ueber einen Codex des Klosters Salem." Zeitschrift für Mathematik und Physik 10:1-16.

Crossley, John N., Alan S. Henry. 1990. "Thus Spoke al-Khwarizmi: A Translation of the Text of Cambridge University Library Ms. Ii. vi.5”. Historia Mathematica 17:103-131.

Datta, B., A. N. Singh. 1935-38. History of Hindu Mathematics. A Source Book. Lahore: Motilai Banarsi Das.

Dodge, Bayard. 1970. The Fihrist of al-Nadim. A Tenth-Century Survey of Muslim Culture. English translation. 2 vols. London/New York: Columbia University Press.

Faulhaber, Charles B. 1983. Medieval Manuscripts in the Library of the Hispanic Society of America. New York: Hispanic Society of America.

Flügel, Gustav. 1871-72. Kitäb al-Fihrist. Mit Anmerkungen herausgegeben von Gustav Flügel, 2 vols. Leipzig: Vogel. 
Folkerts, Menso. 1997. Die älteste lateinische Schrift über das indische Rechnen nach al-Hwārizmī. Edition, Übersetzung und Kommentar von M. Folkerts unter Mitarbeit von Paul Kunitzsch. München: Bayerische Akademie der Wissenschaften, Philosophisch-historische Klasse, Abhandlungen, Neue Folge, Heft 113.

Gandz, Solomon. 1931. "The Origin of the Ghubār Numerals, or the Arabian Abacus and the Articuli." Isis $16: 393-424$.

Gandz, S. 1938. "The Algebra of Inheritance." Osiris 5:319-391.

Hughes, Barnabas B. 1986. "Gerard of Cremona's Translation of al-Khwārizmī’s al-Jabr: A Critical Edition." Mediaeval Studies 48:211-263.

Hughes, Barnabas B. 1989. Robert of Chester's Latin translation of al-Khwārizmì's al-Jabr. A new critical edition. Stuttgart: Franz Steiner.

Ifrah, Georges. 1986. Universalgeschichte der Zahlen. Frankfurt, New York: Campus Verlag.

Irani, Rida A. K. 1955-56. "Arabic numeral forms." Centaurus 4:1-12.

Juschkewitsch, A. P. 1964a. Geschichte der Mathematik im Mittelalter. Leipzig: B. G. Teubner Verlagsgesellschaft.

Juschkewitsch, A. P. 1964b. "Über ein Werk des Abū 'Abdallah Muhammad ibn Mūsā al-Huwārizmī alMağūisī zur Arithmetik der Inder.” In Beiheft zur Schriftenreihe für Geschichte der Naturwissenschaften, Technik und Medizin. Beiträge zur Geschichte der Naturwissenschaften, Technik und Medizin, hg. zum 60. Geburtstag Gerhard Harigs von I. Strube und H. Wußing, 21-63. Leipzig: B. G. Teubner Verlagsgesellschaft.

Juškevič, A. P. 1983. "O trude po arifmetike Muchammada ibn Musy al-Chorezmi." In Muchammad ibn Musa al-Chorezmi. Matematiceskie traktaty, 150-202. Tashkent: Izdatelstvo "FAN."

Karpinski, Louis Charles. 1910-1911. "Hindu numerals in the Fihrist." Bibliotheca Mathematica 3. Folge. 11:121-124.

Karpinski, L. C. 1921. “Two Twelfth Century Algorisms.” Isis 3:396-413.

Kopelevič, Ju. Ch., A. P. Juškevič. 1983. "Muchammad ibn Musa al-Chorezmi, Kniga ob indijskom sčete. Perevod s latinskogo Ju. Ch. Kopelevič i A. P. Juškeviča." In Muchammad ibn Musa al-Chorezmi. Matematičeskie traktaty, 5-19. Tashkent: Izdatelstvo "FAN."

Labarta, Ana, Carmen Barceló. 1988. Números y cifras en los documentos arábigohispanos. Córdoba: Área de Estudios Árabes e Islámicos.

Lemay, Richard. 1982. "Arabic numerals.” In Dictionary of the Middle Ages, edited by Joseph R. Strayer, vol. 1, 382-398. New York: Scribner.

Levey, Martin, Marvin Petruck. 1965. Küshyār ibn Labbān. Principles of Hindu Reckoning. A translation with introduction and notes by Martin Levey and Marvin Petruck of the Kitäb fì usūl hisāb al-hind. Madison and Milwaukee: University of Wisconsin Press.

Lindgren, Uta. 1976. Gerbert von Aurillac und das Quadrivium. Wiesbaden: Franz Steiner.

Pedersen, Fritz S. 1983. Petri Philomenae de Dacia et Petri de S. Audomaro opera quadrivialia. Pars I: Opera Petri Philomenae. Copenhagen: Societas linguae et litterarum Danicarum.

Ruska, Julius. 1917. Zur ältesten arabischen Algebra und Rechenkunst. Heidelberg (Sitzungsberichte der Heidelberger Akademie der Wissenschaften, Philosophisch-historische Klasse, Jahrgang 1917, 2. Abhandlung): Carl Winter's Universitätsbuchhandlung.

Saidan, Aḥmad Salīm. 1973. Abū l-Hasan Aḥmad ibn Ibrāhīm al-Uqlīdisī. Al-Fuṣūl fī l-hisāab al-hindī. Edited by A. Saidan. Amman: Mansurat al-Lagna al-Urdunniya.

Saidan, A. S. 1978. The Arithmetic of al-Uqlìdisī. The Story of Hindu-Arabic Arithmetic as told in Kitāb alFusūl fî̀ al-Hisāb al-Hindī by Abū al-Hasan Ahmad ibn Ibrāhìm al-Uqlīdisī, written in Damascus in the year 341 (A.D. 952/3). Translated and Annotated, from the unique copy, ms. 802 at Yeni Cami Library, Istanbul, written in the year 582 (A.D. 1186). Dordrecht/Boston: Reidel.

Saidan, A. S. ed. 1985. 'Abd al-Qāhir ibn Ṭāhir al-Bag̀dādī: at-Takmila fī'l-hisāb. Kuwait: Mansūrāt mahad al-matūtāt al-arabīya.

Sezgin, Fuat. 1974. Geschichte des arabischen Schrifttums. BandV: Mathematik. Leiden: E. J. Brill.

Smith, David Eugene. 1925. History of Mathematics. Vol. 2. Boston: Ginn. 
Smith, D. E., and L. Ch. Karpinski. 1911. The Hindu-Arabic numerals. Boston/London: Ginn. Steele, Robert. 1922. The Earliest Arithmetics in English. London: Milford.

Thomson, Ron B. 1976. "Jordanus de Nemore: Opera." Mediaeval Studies 38:97-144.

Toomer, Gerald J. 1973. “Al-Khwārizmī.” Dictionary of Scientific Biography. vol. 7, 358-365. New York: Charles Scribner's Sons.

Tropfke, Johannes. 1980. Geschichte der Elementarmathematik, 4. Auflage, Berlin/New York: Walter de Gruyter.

Vogel, Kurt. 1963. Mohammed ibn Musa Alchwarizmi's Algorismus. Das früheste Lehrbuch zum Rechnen mit indischen Ziffern. Nach der einzigen (lateinischen) Handschrift (Cambridge Un. Lib. Ms. Ii. 6.5.) in Faksimile mit Transkription und Kommentar herausgegeben. Aalen: Otto Zeller.

van der Waerden, B. L., Menso Folkerts.1976. History of Mathematics. Counting, Numerals and Calculation. 3: Written Numbers. Milton Keynes: The Open University. 